\title{
Biphenotypic leukaemia: a case of mixed T lymphoblastic and myeloblastic leukaemia
}

\author{
MAM MORGAN, CS SCOTT, J TAVARES DE CASTRO,${ }^{*}$ HJ LIMBERT, N POLLI, ${ }^{*}$ \\ D CATOVSKY,${ }^{*}$ RD PYRAH,$\dagger$ BE ROBERTS
}

From the Department of Haematology, Regional Radiotherapy Centre, Cookridge Hospital, Leeds, the ${ }^{*} M R C$ Leukaemia Unit, Royal Postgraduate Medical School, London, and †Airedale General Hospital, Keighley, W Yorkshire

SUMmARY A case of mixed acute leukaemia with T lymphoblastic, myeloblastic, and monocytic components is described. The use of immunological markers, ultrastructural morphology, cytochemistry, immunochemistry, and combined techniques, simultaneously detecting two markers in individual cells, made it possible to define the different blast cell populations.

Neoplastic disorders are believed to arise from the uncontrolled clonal proliferation of a single progenitor cell. With the use of monoclonal antibody techniques, an increasing number of leukaemias and lymphomas $^{1-3}$ are found to have a mixed phenotype. A biphenotypic leukaemia is one in which leukaemic cell populations with apparent myeloid and lymphoid characteristics coexist. This is in contrast to leukaemias of hybrid phenotype, in which leukaemic cells show phenotypic features of more than one cell line, suggesting the existence of lineage infidelity. ${ }^{4}$ This report describes a case of mixed leukaemia characterised by two distinct populations of blasts: one showed the features of acute $T$ lymphoblastic leukaemia, the other acute myeloblastic leukaemia with some monocytic differentiation. The biphenotypic nature of this leukaemia was established by light microscopy, morphology and cytochemistry, monoclonal antibody studies, and electron microscopy.

\section{Case report}

A 65 year old woman presented with an acute leukaemia. She had a history of general malaise, recurrent infections, mouth ulcers, easy bruising, and weight loss. The salient clinical features were: fever $38^{\circ} \mathrm{C}$, anaemia, bruising on the limbs, $2 \mathrm{~cm} \times$ $1 \mathrm{~cm}$ tender inguinal node, palpable spleen tip, and $6 \mathrm{~cm}$ hepatomegaly. There was no mediastinal mass on a chest radiograph. A full blood count

Accepted for publication 18 January 1985 showed haemoglobin $6.0 \mathrm{~g} / \mathrm{dl}$, white cell count 167 $\times 10^{9} / 1$ (differential $98 \%$ blasts, $2 \%$ lymphocytes, with an occasional granulocyte) and platelet count $65 \times 10^{\%} / 1$. The biochemical profile was normal and Escherichia coli was isolated from a urine culture. A bone marrow aspirate was hypercellular with sheets of blasts, the morphological and immunological features of which are described below.

She received induction chemotherapy with daunorubicin, vincristine, and prednisolone and a bone marrow aspirate performed eight weeks later indicated complete remission. Maintenance chemotherapy was started comprising methotrexate, 6-mercaptopurine, cytosine arabinoside, vincristine, and prednisolone. The patient remains in first remission on maintenance chemotherapy 16 months after presentation.

MATERIAL AND METHODS Light microscopy, morphology, and cytochemistry The morphology of the peripheral blood and bone marrow was examined on May-Grunwald-Giemsa stained smears. Cytochemical staining of blood and bone marrow for myeloperoxidase, Sudan black, chloroacetate esterase, $\alpha$-naphthyl acetate esterase, periodic acid Schiff, and acid phosphatase were performed by standard techniques.

\section{Immunological phenotyping}

Peripheral blood whole leucocyte and mononuclear cell fractions were separated by Plasmagel induced red blood cell rouleaux formation and Lymphoprep density gradient centrifugation respectively. Both fractions comprised in excess of $98 \%$ blasts. Immunological phenotyping was performed by $(a)$ 
detection of cell surface antigens by indirect immunofluorescence of living cell suspensions using a panel of monoclonal antibodies (specificities, sources, and references listed in Table 1); $(b)$ demonstration of terminal deoxynucleotidyl transferase (TdT) with a rabbit anticalf TdT serum by indirect immunofluorescence of methanol fixed cytocentrifuge preparations $\mathbf{s}^{5}$; and (c) E rosetting with sheep red blood cells.

To assess the expression of two markers in the same cell, combinations of TdT with $\mathrm{E}$ rosettes, $3 \mathrm{Al}$, and $\mathrm{My} 9$ were performed as follows: $(a) \mathrm{E}$ rosette preparations were cytocentrifuged, fixed, and processed for TdT as above; (b) $3 \mathrm{Al}$ and $\mathrm{My} 9$ were detected in cell suspension using a fluorescein conjugated secondary antibody, cytocentrifuged cell monolayers prepared, and TdT examined using a rhodamine conjugated secondary antibody. Negative controls were obtained by omitting the primary antibody or by using an irrelevant antibody.

\section{Electron microscopy}

Cells were processed for ultrastructural morphology and detection of myeloperoxidase at electron microscopy level using conventional techniques. ${ }^{6}$ The demonstration of cell surface antigens by monoclonal antibodies and the immunogold method simultaneously with cytoplasmic myeloperoxidase was achieved as previously described. ${ }^{6}$ The monoclonal antibodies used in these combination techniques were. antigranulocyte $\mathrm{FMC} 13 ;^{78}$ antimonocyte FMC17 and FMC $32,{ }^{49} \mathrm{OKMl} ;{ }^{10}$ anti-T cell $3 \mathrm{Al} ;{ }^{11}$ and an anti-HLADr equivalent, FMC4. ${ }^{12}$

\section{RESULTS}

\section{Light microscopy}

Examination of May-Grunwald-Giemsa stained blood and bone marrow smears showed two populations of blasts. About $70 \%$ of these were typical lymphoblasts with a high nuclear to cytoplasmic ratio and convoluted nucleus, while the remainder showed the features of myeloblasts, with a lower nuclear to cytoplasmic ratio, a single nucleolus, and occasional granules in the cytoplasm. Cytochemically, $60 \%$ of blasts showed weak to moderate focal acid phosphatase activity, $10 \%$ of blasts showed weak myeloperoxidase and Sudan black reactivity, and there was no significant chloroacetate esterase, $\alpha$-naphthyl acetate esterase, or periodic acid Schiff activity. These preliminary results indicated two populations of blasts: a minor proportion showing myeloid differentiation with the remainder having the typical acid phosphatase focal positivity suggestive of $T$ cell acute lymphoblastic leukaemia blasts.

Table 1 Immunological phenotype of the blast cells

\begin{tabular}{|c|c|c|c|c|}
\hline Marker & $\%$ Positive cells* & Specificity & Source & Reference \\
\hline \multicolumn{5}{|l|}{ Precursor cells } \\
\hline TdT & 69 & Terminal transferase & PL/Pharmacia & 5 \\
\hline FMC4 & 60 & HLA-Dr & Sera Lab & 12 \\
\hline 12 & 40 & HLA-Dr & Coulter & 28 \\
\hline $\mathrm{J} 5$ & $<1$ & $\begin{array}{l}\text { Common acute lymphoblastic leukaemia } \\
\text { antigen }\end{array}$ & Coulter & 29 \\
\hline \multicolumn{5}{|c|}{ antigen } \\
\hline OKT17 & 50 & T cells & Dr G Goldstein & 30 \\
\hline $3 \mathbf{A} 1$ & 30 & $\mathrm{~T}$ cells & Prof B Haynes & 11 \\
\hline OKT11 & 25 & Sheep red blood cell receptor & Ortho & 13 \\
\hline E-rosettes & 22 & Sheep red blood cell receptor & & \\
\hline UCHT1 & 5 & $\mathrm{~T}$ cells ( $\mathrm{T} 3$ equivalent) & Dr P Beverley & 31 \\
\hline OKT4 & $<1$ & Helper T cells & Ortho & 13 \\
\hline OKT8 & $<1$ & Suppressor T cells & Ortho & 13 \\
\hline OKT6 & $<1$ & Cortical thymocytes & Ortho & 13 \\
\hline HTA-1 (NA1/34) & $<1$ & Cortical thymocytes & Sera Lab & 32 \\
\hline \multicolumn{5}{|l|}{ Myeloid cells } \\
\hline My & 14 & Granulocytes, monocytes, and precursors & Coulter & 33 \\
\hline & 13 & $\begin{array}{l}\text { Early granulocytes, monocytes, and } \\
\text { precursors }\end{array}$ & Coulter & 34 \\
\hline FMC17 & 14 & Predominantly monocytes/macrophages & Dr H Zola & 9 \\
\hline FMC32 & 7 & Predominantly monocytes/macrophages & Dr H Zola & 9 \\
\hline LeuM3 & 10 & Predominantly monocytes/macrophages & Becton-Dickinson & 35 \\
\hline My4 & 11 & Predominantly monocytes/macrophages & Coulter & 33 \\
\hline UCHM1 & 9 & Predominantly monocytes/macrophages & Dr P Beverley & 36 \\
\hline $61 \mathrm{D3}$ & $<1$ & Predominantly monocytes/macrophages & BRL & 35 \\
\hline Mo2 & $<1$ & Predominantly monocytes/macrophages & Coulter & 37 \\
\hline \multirow{3}{*}{$\begin{array}{l}\text { Other lineages } \\
\text { LICR/LON/R10 } \\
\text { AN51 } \\
\text { B1 }\end{array}$} & & & DEdou & \\
\hline & $<1$ & Glycophorin A, erythroid cells & Dr P Edwards & 38 \\
\hline & $\begin{array}{l}<1 \\
<1\end{array}$ & $\begin{array}{l}\text { Platelet glycoprotein Ib } \\
\text { B cells }\end{array}$ & $\begin{array}{l}\text { Prof A McMichael } \\
\text { Coulter }\end{array}$ & $\begin{array}{l}39 \\
40\end{array}$ \\
\hline
\end{tabular}

*Blasts comprised in excess of $98 \%$ of the leucocyte fraction tested. 


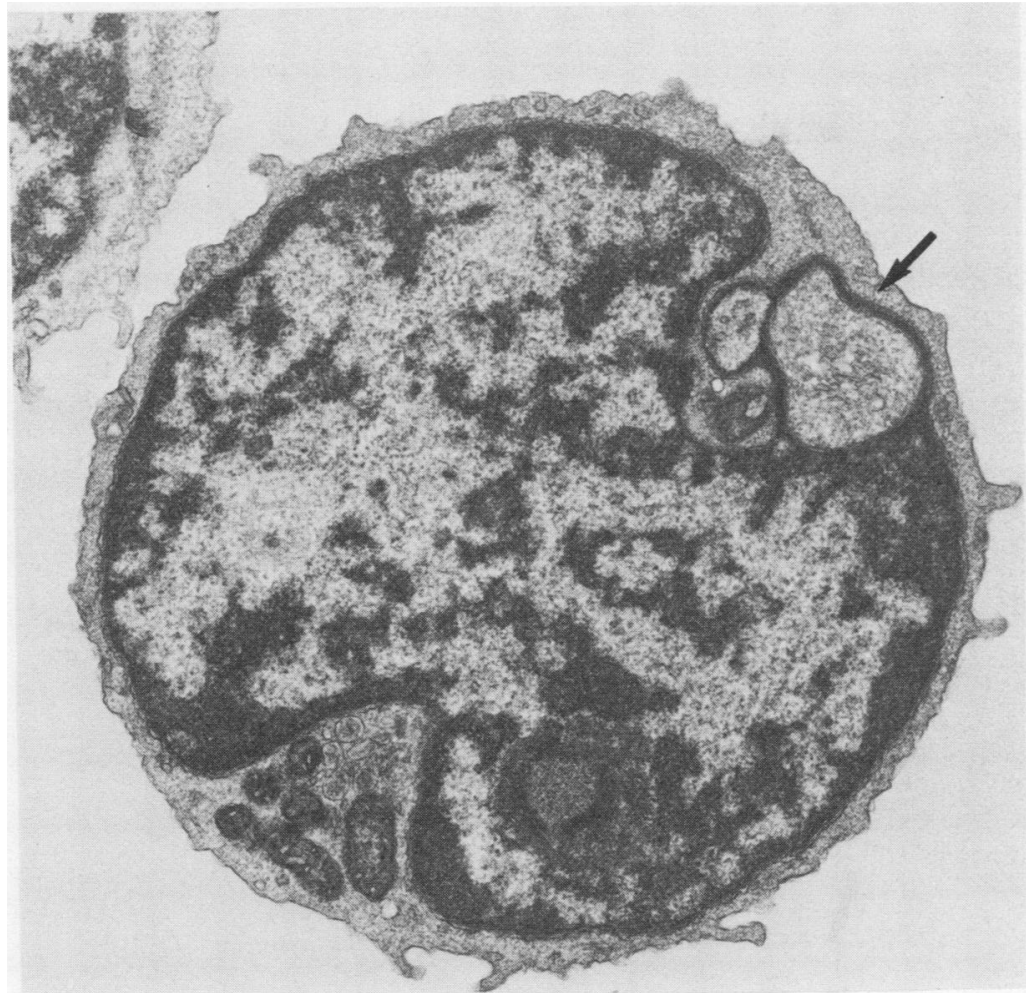

Fig. 1 Lymphoblast. Note the high nuclear to cytoplasmic ratio, the inconspicuous nucleolus, and two nuclear pockets (arrow). Uranyl acetate and lead citrate staining. Original magnification $\times 18500$.

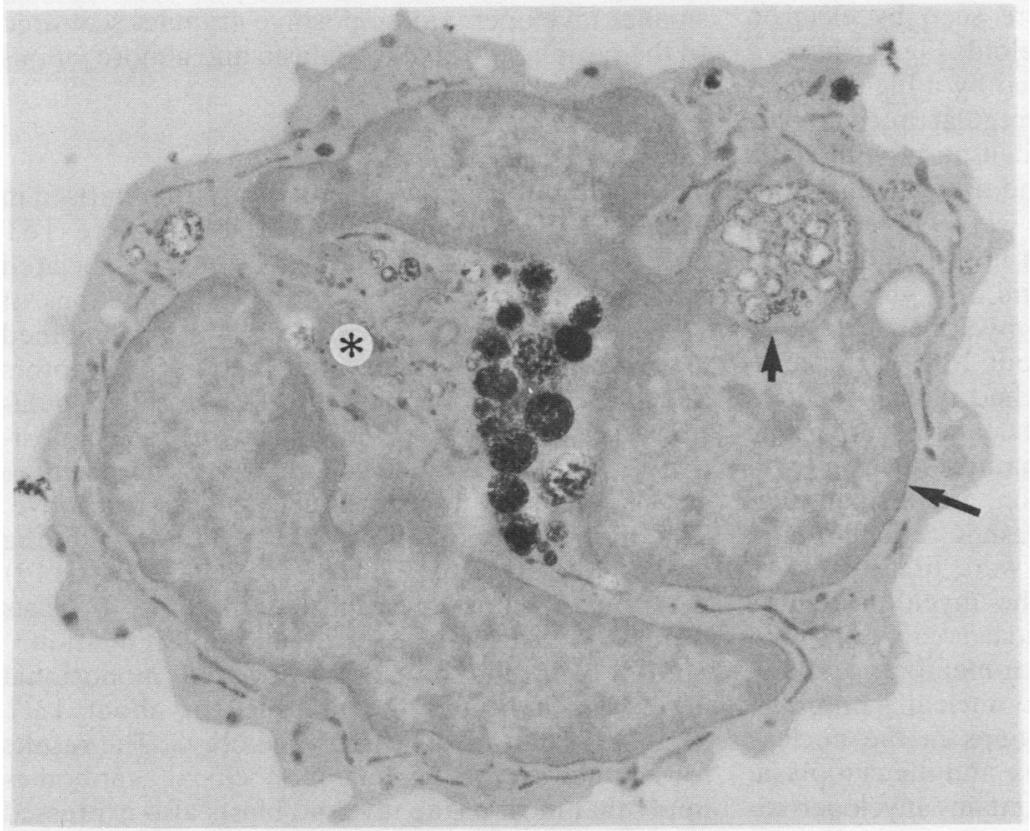

Fig. 2 Myeloblast,

myeloperoxidase reaction. Note the presence of myeloperoxidase activity in the perinuclear space (small arrow), rough endoplasmic reticulum, Golgi apparatus (asterisk), and small and medium sized granules. This pattern indicates active synthesis of the enzyme in an immature cell. $A$ nuclear pocket (large arrow) encloses an area of cytoplasm containing myeloperoxidase reactive material. Original magnification $\times 14700$. 


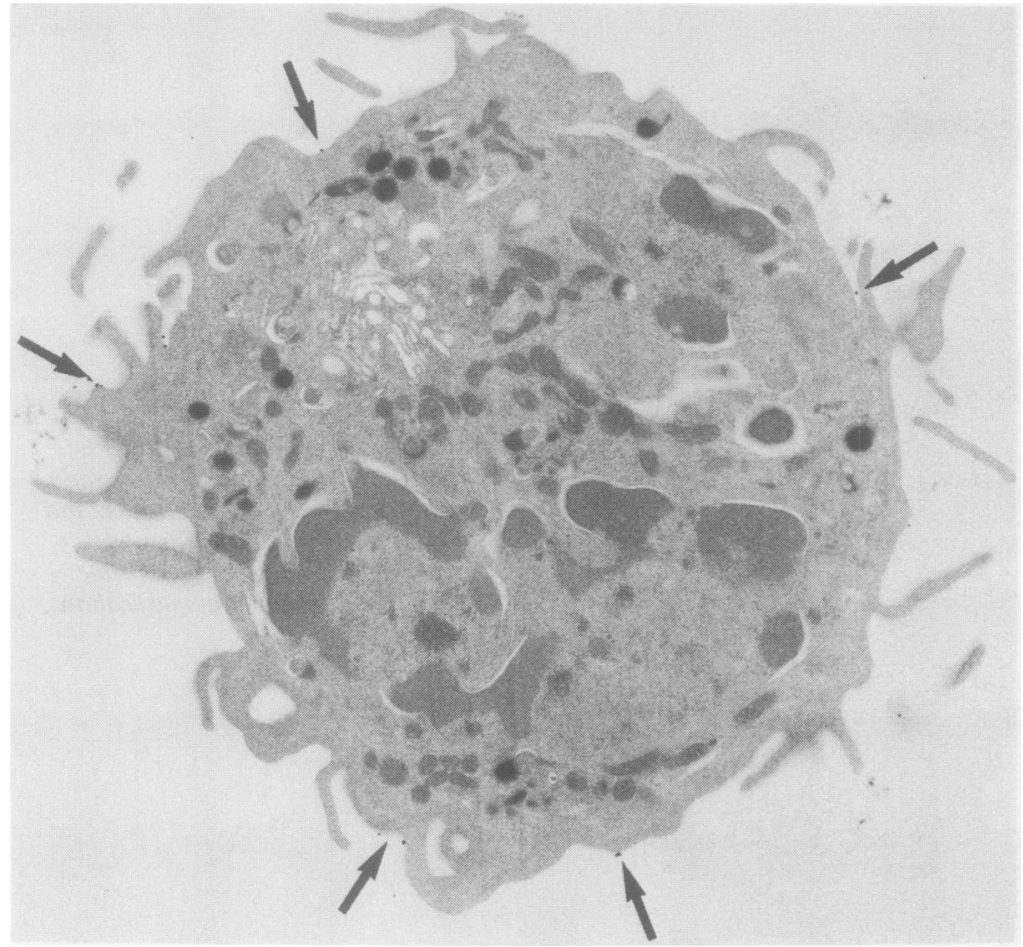

Fig. 3 Monocytoid cell, combined detection of a monocytic antigen (FMC32) and myeloperoxidase. The small myeloperoxidase containing granules and the villous cytoplasmic outline are characteristic of the monocytic lineage. The $30 \mathrm{~nm}$ gold particles attached to the cell membrane are signalled by arrows. Original magnification $\times 18400$.

Ultrastructural morphology and myeloperoxidase cytochemistry

Two populations of blasts were seen by electron microscopy: lymphoid and myeloid. Fig. 1 shows a typical lymphoblast characterised by a high nuclear to cytoplasmic ratio, slightly irregular nuclear outline, peripheral chromatin condensation with some patches of heterochromatin, and a small ring form nucleolus. Nuclear pockets were noted in a significant number of cells with both lymphoid and myeloid morphology (Figs. 1 and 2). Lymphoblasts were uniformly unreactive for myeloperoxidase. A second population of blasts, about $20 \%$ of the cells, was myeloperoxidase positive, had typical features of myeloblasts, with a lower nuclear to cytoplasmic ratio than lymphoblasts, immature nucleus with marginal chromatin condensation, and a small nucleolus. Short strands of endoplasmic reticulum and large to medium size granules were present in the cytoplasm of these cells. In the myeloblast illustrated in Fig. 2 the myeloperoxidase reaction is seen in the granules, in the perinuclear membrane, and in the endoplasmic reticulum. The nuclear membrane limiting the heterochromatin loops in the nuclear pocket contains myeloperoxidase and the cytoplasm enclosed by these loops also contains myeloperoxi- dase reactive granules and mitochondria. Some of the myeloid cells showed monocytic features with smaller myeloperoxidase positive granules scattered to the periphery of the cytoplasm and a more villous cytoplasmic outline (Fig. 3).

\section{Immunological studies}

The results of these investigations are summarised in Table 1 . The majority $(69 \%)$ of blasts were TdT positive, while the expression of $T$ lineage associated determinants indicated appreciable populations of $3 \mathrm{Al}, \mathrm{OKT} 17$, and T11 positive blasts. A combined assay for membrane sheep red blood cell receptors and nuclear TdT defined three blast cell populations: (a) sheep red blood cell positive, TdT positive; (b) sheep red blood cell negative, TdT positive; and $(c)$ sheep red blood cell negative, TdT negative. The partial expression of $\mathrm{T} 11$ together with the absence of detectable T4, T8, T6, and T1 (UCHT2) determinants further suggested that the $T$ blasts were at an early stage of thymic differentiation..$^{13}$ Studies with the myeloid associated monoclonal antibodies indicated the presence of about $13 \%$ My9/My7 (pan-myeloid) positive blasts. The results for monocyte associated monoclonal antibodies imply that most of the myeloid blasts also expressed 
Table 2 Morphological, cytochemical, and immunological characteristics of the different blast cell populations

\begin{tabular}{|c|c|c|c|c|c|c|c|c|c|c|}
\hline \multirow[t]{2}{*}{ Blast type } & \multirow[t]{2}{*}{$\%^{*}$} & \multirow[t]{2}{*}{ Morphology } & \multicolumn{2}{|l|}{ Cytochemistry } & \multicolumn{6}{|c|}{ Immunological phenotype } \\
\hline & & & Myeloperoxidase & Acid phosphatase & $T d T$ & $E / T 11$ & $3 A 1 / T 17$ & $M y 9 / M y 7$ & $F M C 17 / 32$ & $F M C 13$ \\
\hline$T$ blasts & 70 & $\begin{array}{l}\text { Small blasts with high } \\
\text { nuclear to cytoplasmic } \\
\text { ratio }\end{array}$ & - & Focal & + & $-1+$ & $-1+$ & - & - & - \\
\hline Myeloid & 30 & $\begin{array}{l}\text { Blasts show lower } \\
\text { nuclear to cytoplasmic } \\
\text { ratio; some show } \\
\text { villous outline }\end{array}$ & $\begin{array}{l}\text { Medium-large or } \\
\text { small granules }\end{array}$ & - & $-\dagger$ & - & - & + & $-1+\ddagger$ & $-1+\S$ \\
\hline
\end{tabular}

*Studies performed when the peripheral blood white cell count was $167 \times 10^{\%} / 1$. Leucocyte fractions for immunological studies contained in excess of $95 \%$ blasts.

$+2 \%$ of blasts coexpressed My 9 and TdT.

${ }_{7}^{+}$Positive in monocytic cells.

$\S$ Positive in granulocytic cells.

FMC32, OKM5, UCHM1, LeuM3, and My4 but not Mo2 or $61 \mathrm{D} 3$ determinants. These findings support the observations of electron microscopy which suggested a monocytic component, although their lack of cytochemical $\alpha$-naphthyl acetate esterase activity and absence of monocyte specific $\alpha$-naphthyl acetate esterase isoenzymes (as assessed by isoelectric focusing) indicated these blasts to be at a relatively early stage of monocytic differentiation. ${ }^{14}$

\section{Electron immunocytochemistry}

Monoclonal antibody FMC13 (granulocyte associated) was reactive with the more mature granulocytic cells (myelocytes and metamyelocytes) while the majority of myeloblasts in this case were unreactive. Monoclonal antibodies FMC17 and FMC32 (monocyte associated) were reactive with about $10 \%$ of the blasts and these cells tended to have monocytoid features (Fig. 3). Monoclonal antibody OKM1 was reactive with both myeloblasts and blasts with monocytic features, although some OKM1 positive cells were myeloperoxidase negative.

$3 \mathrm{Al}$ positive cells invariably corresponded to blasts with lymphoid morphology. $3 \mathrm{Al}$ negative cells were either myeloperoxidase positive or negative. The first subset had the morphological characteristics of myeloid cells, whereas myeloperoxidase negative cells comprised the lymphoid population. $3 \mathrm{Al}$ and myeloperoxidase were mutually exclusive markers because they did not appear to coexist in any of the cell types examined.

Table 2 summarises the characteristics of the different blast cell populations in this case, defined by the integration of different techniques.

\section{Discussion}

This report describes a case of mixed $\mathrm{T}$ cell acute lymphoblastic and acute myeloblastic leukaemia which was defined by extensive laboratory studies. The combination of the immunogold method with myeloperoxidase cytochemistry was particularly important in this case because $(a)$ it confirmed the mutual exclusion in individual cells of the antigen detected by $3 \mathrm{Al}$ and cytoplasmic myeloperoxidase, and $(b)$ it was possible to dissect in the myeloid (myeloperoxidase positive) component two subpopulations of blasts-myeloblasts (FMC17/32-) and promonocytes (FMC17/32+). The identification of the $3 \mathrm{~A} 1$ reactive cells as non-myeloid (myeloperoxidase negative) is important because $3 \mathrm{Al}$ has been shown to react in some cases with a fraction of myeloid cells. ${ }^{15}$

In this case the demonstration of a $\mathrm{T}$ cell component was based on the presence of surface markers defined by $\mathrm{E}$ rosettes/OKT11, 3Al, and OKT17. The last two antibodies appear to be more sensitive in detecting early $T$ cell differentiation than $E$ rosettes as up to $30 \%$ of $\mathrm{T}$ cell acute lymphoblastic leukaemia cases (pre-T-ALL) are $E$ rosette and OKT11 negative and only detectable by their reactivity with $3 \mathrm{Al} .^{16}$

The observation of nuclear blebs in both lymphoblasts and myeloblasts by electron microscopy in this case is another interesting feature. These structures have been previously identified in leukaemias and, infrequently, in normal blood cells. In general, they represent the ultrastructural expression of disturbances of DNA metabolism or nuclear membrane formation or both. In acute leukaemia a correlation between aneuploidy and a high frequency of nuclear blebs has been reported. ${ }^{17}$

Previously reported cases of mixed lymphoblastic myeloid leukaemia, either arising de novo or related to treatment, usually have lymphoblasts of the common or null cell phenotype. ${ }^{18-22}$. There are a number of case reports describing the sequential occurrence of a $\mathrm{T}$ cell leukaemia and acute or chronic myeloid leukaemia, ${ }^{23-25}$ although we believe 
that this is the first reported case of a de novo mixed acute leukaemia in which there is evidence of $T$ cell differentiation in the lymphoid lineage.

The association of a myeloblastic and $T$ lymphoblastic phenotype in this case could be attributed to the coexistence of two abnormal clones arising from two separate cells ${ }^{26}$ or, alternatively, they may have arisen from a single progenitor cell with differentiation along two lineages. The recognition of biphenotypic leukaemias is important so that appropriate chemotherapy can be given. In leukaemias with potential for differentiation along two pathways, cytotoxic treatment aimed specifically at one lineage may not be curative and relapse may occur with blasts characteristic of the untreated lineage. ${ }^{27}$ Our patient was treated with a standard treatment for adult acute lymphoblastic leukaemia (UKALL IX regimen) that incorporates daunorubicin, vincristine, and prednisolone. It is of interest that a complete remission was achieved and maintained with treatment that is not totally appropriate for acute myeloid leukaemia. This study also confirms the value of immunological studies and electron microscopy in the characterisation of mixed leukaemias.

We thank Dr DJ Maberly, Airedale General Hospital, and Dr AG Bynoe for their help in this investigation. JTC was supported by the Calouste Gulbenkian Foundation, Portugal, and NP by the Associazione Italiana per la Ricerca sue Cancro.

\section{References}

' Pui C, Dahl GV, Melvin S, et al. Acute leukaemia with mixed lymphoid and myeloid phenotype. $\mathrm{Br} J$ Haematol 1984;56:121-30.

${ }^{2}$ Biphenotypic leukaemia. Editorial. Lancet 1983;ii:8360-1.

${ }^{3}$ Sklar J, Cleary ML, Thielemans K, Gralow J, Warnke R, Levy R. Biclonal B-cell lymphoma. $N$ Engl J Med 1984;311:20-7.

${ }^{4}$ Smith JL, Curtis JE, Messner HA, Senn JS, Furthmayr H, McCulloch EA. Lineage infidelity in acute leukemia. Blood 1983;61:1138-44.

${ }^{5}$ Bollum FJ. Terminal deoxynucleotidyl transferase as a haematopoietic cell marker. Blood 1979;54:1203-15.

- Robinson D, Tavares De Castro J, Polli N, O' Brien M, Catovsky D. Simultaneous demonstration of membrane antigens and cytochemistry at ultrastructural level: A study with the immunogold method, acid phosphatase and myeloperoxidase. Br J Haematol 1984; 56:617-31.

' Zola H, McNamara P, Thomas M, Smart I, Bradley J. The preparation and properties of monoclonal antibodies against human granulocyte membrane antigens. $\mathrm{Br} \mathrm{J}$ Haematol 1981;48:481-90.

${ }^{8}$ Polli N, Zola H, Catovsky D. Characterization by ultrastructural cytochemistry of normal and leukemic myeloid cells reacting with monoclonal antibodies. Am J Clin Pathol (in press).

' Brooks DA, Zola H, McNamara P, et al. Membrane antigens of human cells of the monocyte/macrophage lineage studied with monoclonal antibodies. Pathology 1982;15:45-52.
${ }^{10}$ Breard J, Reinherz EL, Kung P, Goldstein G, Schlossman SF. A monoclonal antibody reactive with human peripheral blood monocytes. J Immunol 1980; 127: 1943-8.

"Haynes BF, Metzgar RS, Minna JD, Bunn PA. Phenotypic characterization of cutaneous T-cell lymphoma. Use of monoclonal antibodies to compare with other malignant T-cells. $N$ Engl J Med 1981;304:1319-23.

12 Beckman IGR, Bradley J, Brooks DA, et al. Human lymphocyte markers defined by antibodies derived from somatic cell hybrids. II. A hybridoma secreting antibody against an antigen expressed by human B and null lymphocytes. Clin Exp Immunol 1980;40:593-601.

${ }^{13}$ Reinherz EL, Kung PC, Goldstein G, Levey RH, Schlossman SF. Discrete stages of human intrathymic differentiation: Analysis of normal thymocytes and leukemic lymphoblasts of T-cell lineage. Proc Natl Acad Sci USA 1980;77:1588-92.

${ }^{14}$ Scott CS, Linch DC, Bynoe AG, et al. Electrophoretic and cytochemical characterization of alpha-naphthyl acetate esterases in acute myeloid leukemia: Relationships with membrane receptor and monocyte-specific antigen expression. Blood 1984;63:579-87.

is Van der Reijden HJ, Van Rhenen DJ, Lansdorp PM, et al. A comparison of surface marker analysis of FAB classification in acute myeloid leukemias. Blood 1983;61:443-8.

${ }^{16}$ Catovsky D, San Miguel JF, Soler J, et al. T-cell leukemias: Immunologic and clinical aspects. J Exp Clin Cancer Res 1983;2:229-33.

17 Ahearn MJ, Trujillo JM, Cork A, Fowler A, Hart JS. The association of nuclear blebs with aneuploidy in human acute leukaemia. Cancer Res 1974;34:2887-96.

${ }^{18}$ Catovsky D, De Salvo Cardullo L, O'Brien M, et al. Cytochemical markers of differentiation in acute leukemia. Cancer Res 1981;41:4824-32.

10 Parkin JL, Arthur DC, Abramson CS, et al. Acute leukemia associated with the $t(4 ; 11)$ chromosome rearrangement: Ultrastructural and immunological characteristics. Blood 1982;60:1321-31.

${ }^{20}$ Perentesis J, Ramsey NKC, Brunning RD, Kersey JH, Filipovich A. Biphenotypic leukaemia: Immunological and morphological evidence for a common lymphoid-myeloid progenitor in humans. J Paed 1983; 102:63-7.

2' Prentice AG, Smith AG, Bradstock KF. Mixed lymphoblasticmyeloblastic leukaemia in treated Hodgkins disease. Blood 1980;56:129-33.

${ }^{22}$ Mertelsmann R, Koziner B, Ralph P, et al. Evidence for distinct lymphocytic and monocytic populations in a patient with terminal transferase-positive acute leukemia. Blood 1978;51: 1051-6.

${ }^{23}$ Hernandez P, Carnot J, Cruz C. Chronic myeloid leukaemia blast crisis with T cell features. $B J$ Haematol 1982;51:175-6.

${ }^{24}$ Griffin J, Tantravatti R, Canellos G, et al. T-cell surface antigens in a patient with blast crisis of chronic myeloid leukemia. Blood 1983;61:640-4.

2s Dankbaar H, Willemze R, Spaander PJ, Geraedts JPM. Philadelphia chromosome positive T-ALL. Br J Haematol 1982;50:543-8.

${ }^{26}$ Greaves MF. Tumour markers, phenotypes and maturation arrest in malignancy: A cell selection hypothesis. In: Boelmsa E, Rumke P, eds. Tumour Markers, Amsterdam: Elsevier, 1979:201-11.

${ }^{27}$ Murphy SB, Stass S, Kalwninsky D, Rivera G. Phenotypic conversion of acute leukaemia from T-lymphoblastic to myeloblastic induced by therapy with $2^{\prime}$-deoxyformycin. $\mathrm{Br} J$ Haematol 1983;55:285-93.

${ }^{28}$ Nadler LM, Stashenko P, Handy R, et al. Monoclonal antibodies defining serologically distinct HLA-D/Dr related Ia-like antigens in man. Human Immunol 1981;1:77-81.

${ }^{24}$ Ritz J, Pesando JM, Notis-McConarty J, Lazarus H, Schlossman SF. A monoclonal antibody to human acute lymphoblastic leukaemia antigen. Nature 1980;283:583-5. 
${ }^{30}$ Thomas Y, Rogozinski L, Irigoyen $\mathrm{OH}$, et al. Functional analysis of human $\mathrm{T}$ cell subsets defined by monoclonal antibodies. $\mathrm{V}$. Suppressor cells within the activated OKT4+ population belong to a distinct subset. $J$ Immunol 1982;128:1386-90.

${ }^{31}$ Beverley PCL, Callard RE. Distinctive functional characteristics of human $\mathrm{T}$ lymphocytes defined by $\mathrm{E}$ rosetting or a monoclonal anti-T cell antibody. Eur J Immunol 1981;11:329-34.

${ }^{32}$ McMichael AJ, Pilch JR, Galfre G, Mason DY, Fabre JW, Milstein C. A human thymocyte antigen defined by a hybrid myeloma monoclonal antibody. Eur J Immunol 1979;9:20510.

${ }^{33}$ Griffin JD, Mayer RJ, Weinstein JH, et al. Surface marker analysis of acute myeloblastic leukemia: Identification of differentiation-associated phenotypes. Blood 1983;62:55763.

${ }^{34}$ Griffin JD, Linch D, Sabbath K, Larcom P, Schlossman SF. A monoclonal antibody reactive with normal and leukemic human myeloid progenitor cells. Leuk Res 1984;8:521-34.

${ }^{35}$ Dimitriu-Bona A, Burmester GR, Waters SJ, Winchester RJ. Human mononuclear phagacyte differentiation antigens. I. Patterns of antigenic expression on the surface of human monocytes and macrophages defined by monoclonal antibodies. J Immunol 1983; 130:145-52.
${ }^{36}$ Linch DC, Allen C, Beverley PCL, Bynoe AG, Scott CS, Hogg N. Monoclonal antibodies differentiating between monocytic and non-monocytic variants of AML. Blood 1984;63:573-8.

37 Todd RF III, Schlossman SF. Analysis of antigenic determinants on human monocytes and macrophages. Blood 1982;59:77586.

${ }^{38}$ Greaves MF, Sieff C, Edwards PAW. Monoclonal antiglycophorin as a probe for erythroleukaemias. Blood 1983;61:645-51.

${ }^{34}$ Vainchenker W, Deschamps JF, Bastin JM, et al. Two monoclonal antiplatelet antibodies as markers of human megakaryocyte maturation: Immunofluorescent staining and platelet peroxidase detection in megakaryocyte colonies and in vivo cells from normal and leukemic patients. Blood 1982;59:514-21.

${ }^{40}$ Stashenko P, Nadler LM, Hardy R, Schlossman SF. Characterization of a human B lymphocyte-specific antigen. J Immunol 1980;125: 1678-85.

Requests for reprints to: Dr CS Scott, Department of Haematology, Regional Radiotherapy Centre, Cookridge Hospital, Leeds LS16 6QB, England. 